\title{
MEDZI ZAMESTNANCOM A SAMOSTATNE ZÁROBKOVO ČINNOU OSOBOU
}

\author{
ANDREJ PORUBAN*
}

\begin{abstract}
Between an employee and an independent contractor
This paper aims at discussing the new approach to regulating the so-called platform work by looking at the main initiatives. It briefly describes the pros and cons of potential thirdcategory between employees and independent contractors and potential.
\end{abstract}

Keywords: employment relationship; employee; independent contractor; third category

Klíčová slova: pracovnoprávny vztah; zamestnanec; samostatne zárobkovo činná osoba; tretia kategória

DOI: $10.14712 / 23366478.2019 .8$

\section{ÚVOD}

Moderné technológie intenzívne transformujú pracovné právo už viac ako dve dekády. Spočiatku ich vpád súvisel s prehlbovaním dispozičnej právomoci zamestnávatel'a. To sa týka predovšetkým zásahov do súkromia zamestnancov (napr. monitorovanie pracoviska, zaznamenávanie telefonických hovorov, kontrola elektronickej pošty), či zintenzívňovaním pracovnej zát'aže (zamestnanec na telefóne 24 hodín denne, práca doma mimo rozvrhu pracovných zmien, atd’.). Dnes dochádza k ovplyvňovaniu spôsobov organizácie práce aj inak. S dostupnost’ou internetu a inteligentných telefónov dochádza k väššiemu dopytu po flexibilnejších typoch zamestnávania. Pre informačno-komunikačným nástrojom sa interný zamestnanec $\mathrm{v}$ klasickom pracovnoprávnom vzt’ahu stáva čím d’alej menej žiadaný. Jeho činnost' je nahradzovaná ad hoc poskytovatel'mi služieb, ktorí sa pohybujú v online sfére. Riadenie pracovného procesu sa uskutočňuje automatizovaným spracovaním vel'kého množstva dát a prostredníctvom algoritmov.

\footnotetext{
* Autor je odborným asistentom na katedre pracovného práva a práva sociálneho zabezpečenia Právnickej fakulty Univerzity Komenského v Bratislave. Príspevok vznikol v rámci riešenia projektu Vedeckej grantovej agentúry Ministerstva školstva, vedy, výskumu a športu Slovenskej republiky a Slovenskej akadémie vied (VEGA) reg. číslo 1/0908/17 pod názvom Zamestnávanie mladých l'udí v čase hospodárskych zmien vo svetle migračnej krízy - nové výzvy pre politiku trhu práce (právny a - ekonomický pohlad).
} 


\section{VYTVORENIE TRETEJ KATEGÓRIE}

Pod tlak sa tak dostáva aj zaužívaná taxonómia, ktorá sa odvíja od definície závislej práce. Dvojkol'ajnost' zamestnanec vs. samostatne zárobkovo činná osoba sa uplatňuje i v našich právnych poriadkoch. ${ }^{1} \mathrm{~S}$ rastom neštandardných foriem práce je spojená tiež otázka, kto už spadá do prvej skupiny a kto ešte nie, čo vedie k návrhom právnych a politických reforiem. ${ }^{2}$ Do úvahy pripadá niekol'ko základných alternatív ${ }^{3}$ :

i/ prehodnotenie všetkých právnych predpisov a ich prispôsobenie na podmienky platformovej práce,

ii/ vyňatie zo súčasného právneho rámca a vytvorenie špeciálnej úpravy,

iii/ vytvorenia hybridnej kategórie na pomedzí zamestnancov a samostatne zárobkovo činnými osobami ${ }^{4}$.

\section{VÝHODY TRETEJ KATEGÓRIE}

Posledná možnost ${ }^{5}$ vychádza z tradičných rozdielov medzi zamestnancami a nezávislými dodávatel'mi, ktoré však strácajú relevanciu pre čoraz väčšiu čast' pracovnej sily. Súčasné rozlišovanie vytvára nejasnosti a administratívnu zát’až a nie je zrejmé, ako sa takéto delenie zhoduje s ciel'mi pracovného práva. ${ }^{6}$ Väčšina kl'účových práv, ktoré sú spriaznené s ochranou slabšej zmluvnej strany, je k dispozící́ iba zamestnancom (hlavne zákaz svojvol'ného prepúšt’ania, nárok na minimálnu mzdu, najvyššia prípustná dížka pracovného času, primeraný odpočinok po práci, najkratšia prípustná dížku platenej dovolenky na zotavenie, právo slobodne sa združovat' v odboroch a na kolektívne vyjednávanie + špecifické právo na sociálne zabezpečenie). Ich rozšírenie aj

1 § 1 ods. 2 Zákonníka práce č. 311/2001 Z. z.: „Závislá práca je práca vykonávaná vo vzt'ahu nadriadenosti zamestnávatel'a a podriadenosti zamestnanca, osobne zamestnancom pre zamestnávatel'a, podl'a pokynov zamestnávatel'a, v jeho mene, v pracovnom čase určenom zamestnávatel'om."

$\S 2$ Zákoníku práce č. 262/2006 Sb.:

„(1) Závislou praci je práce, která je vykonávána ve vztahu nadřizenosti zaměstnavatele a podřizenosti zaměstnance, jménem zaměstnavatele, podle pokynů zaměstnavatele a zaměstnanec ji pro zaměstnavatele vykonává osobně.

(2) Závislá práce musí být vykonávána za mzdu, plat nebo odměnu za práci, na náklady a odpovědnost zaměstnavatele, v pracovní době na pracovišti zaměstnavatele, popripadě na jiném dohodnutém mistě."

2 JOHNSTON, H. - LAND-KAZLAUSKAS, C. Organizing on-demand: Representation, voice, and collective bargaining in the gig economy. Conditions of work and employment series. Geneva: ILO, 2018, no. 94, p. 32.

3 Napr. KENNEDY, J. V. Three Paths to Update Labor Law for the Gig Economy, s. 2. Dostupné online na: $<$ http://www2.itif.org/2016-labor-law-gig-economy.pdf $>$.

4 V slovenskej literatúre o modeli hybridného zamestnanca hovorí BARANCOVÁ, H. Zamestnanec, štatutár a spoločník v pracovnom práve. Praha: Leges, 2018, s. 20.

5 Nejde o úplne prevratnú myšlienku. S kvázi zamestnancami sa môžeme s určitými osobitost'ami stretnút' už teraz v Taliansku (lavoratori parasubordinati), v Nemecku (arbeitnehmerähnliche Personen), Izraeli, Španielsku, Portugalsku, Vel'kej Británii či Kanade. Viac Non-standard employment around the world: Understanding challenges, shaping prospects. Geneva: ILO. 2016, s. 37-39.

6 ADAMS, A. - FREEDMAN, J. - PRASSL, J. Rethinking Legal Taxonomies For The Gig Economy. Oxford Review of Economic Policy, 2018, vol. 34, č. 2. 
na ostatných pracujúcich bez ohl'adu na právne postavenie by pritom nemuselo neprimerane ekonomicky poškodzovat' potenciál platformovej práce. ${ }^{7} \mathrm{~V}$ neposlednom rade sa tu otvára priestor na využívanie predností z oboch pôvodných kategóriii ${ }^{8}$, napr. pracovnoprávna ochrana spolu s výhodami v daňovej a odvodovej oblasti.

\section{NEVÝHODY TRETEJ KATEGÓRIE}

Kreovanie tretej kategórie nie je všeliek na problémy, ktorým čelí pracovné právo v 21. storočí. Bez poznania konkrétneho obsahu práv, ktoré by k nej patrili, je t’ažké posúdit' jej pozitíva. ${ }^{9}$ Napriek tomu sa domnievam, že zavedenie autonómnej kategórie by nebolo užitočné. Nepovedie k efektívnejšiemu fungovania celého systému, ale spôsobí skôr jeho neprehl'adnost'. Hlavný problém rigidného binárneho rozlišovania síce zmizne. Čiary oddel'ujúce jednotlivé kategórie sa však nezrušia, ale zdvojnásobia. Hranice budú stále rovnako neisté a nebudú vždy vyhovovat' situáciám, ktoré môže trh práce priniest'. Vylúčit' nemožno ani vznik nových otázok a možné nezamýšl'ané vedl'ajšie účinky. ${ }^{10}$ Okrem toho intermediárna kategória by nemala byt’ chápaná ako riešenie nesprávnej klasifikácie tzv. falošných/nútených živností. ${ }^{11}$

\section{ZÁVER}

Na jednej strane je nutné uznat', že charakterizujúce kritéria statusu zamestnanca podl'a definície závislej práce nie sú optimálne. Na strane druhej sú stále dostatočne pružné, aby sa mohli aplikovat’ aj na neštandardné formy zamestnávania. Posúdenie bude individuálne a bude vždy závisiet’ od okolností toho-ktorého prípadu. Z hl'adiska závislej práce ako podstaty pracovného práva ide iba o pokračovanie neustálych konfliktov, čo ešte je pracovnoprávny vzt’ah a čo už podnikanie. Digitálna éra si jednoznačne vyžaduje prispôsobenie sa realite. Lenže primárnou požiadavkou bez potreby koncepčných zásahov do pracovného práva - by mali byt’ nové prístupy $\mathrm{k}$ interpretovaniu prvkov nesamostatnej práce. Tie sa dotýkajú najmä znakov ako subordinácia, podl'a pokynov, v mene zamestnávatel'a a v pracovnom čase určenom zamest-

7 FLORISSON, R. - MANDL, I. Platform work: Types and implications for work and employment - Literature review. Luxembourg: Publications Office of the European Union, s. 96.

8 Z perspektívy osobnej a vecnej pôsobnosti práva Európskej únie sa ako nevyhnutná javí aj d’alšia existencia večnej dichotómie medzi pracovníkom a samostatne zárobkovo činnou osobou podl'a právnych predpisov Európskej únie. Európski zákonodarcovia ani Súdny dvor Európskej únie vo svojej judikatúre zatial' nezaviedli akúkol'vek prechodnú kategóriu. In BEDNAROWICZ, B. Decent Work in the Gig Economy under European Union Law: Utopia or Dystopia? Príspevok prednesený na ILERA World Congress 2018.

9 ALOISI, A. - CHERRY, M. A. A Third Employment Category for On-Demand Workers? Oxford Business Law Blog, 2016. Dostupné online na: <https://www.law.ox.ac.uk/business-law-blog/blog/2016/11/third -employment-category-demand-workers $>$.

10 DE STEFANO, V. - HENDRICKX, F. Gig economy, platform work, and the binary worker categorisation. In: SOMERS. M. (ed.). Vorm geven aan digitale tijden. Sint-Gillis: Denktank Minerva, 2018, s. 108.

11 DAVIDOV, G. - FREEDLAND, M. - KOUNTOURIS, N. The Subjects of Labour Law: 'Employees' and other Workers. In: FINKIN, M. - MUNDLAK, G. (eds.). Comparative Labor Law. Cheltenham: Edward Elgar. 2015, s. 115-131. 
návatel'om, ktoré sa môžu javit' ako sporné. To však nie je žiadna novinka, ale vd’aka platformovej práci sa opät' vraciame $\mathrm{k}$ fundamentálnym otázkam pracovného práva ako relatívne samostatného právneho odvetvia.

JUDr. Andrej Poruban, PhD.

Katedra pracovného práva a práva sociálneho zabezpečenia

Právnická fakulta Univerzity Komenského v Bratislave

andrej.poruban@flaw.uniba.sk 